\title{
Sustainable Production and Consumption of Paper and Paper Products in Nigeria: A Review
}

\author{
Obiora B. Ezeudu ${ }^{1, *}$, Jonah C. Agunwamba ${ }^{2}$, Ikenna C. Ezeasor ${ }^{1}$ and Christian N. Madu ${ }^{1,3}$ \\ 1 SHELL Centre for Environmental Management and Control, University of Nigeria, Enugu Campus 410001, \\ Nigeria; ikenna.ezeasor@unn.edu.ng (I.C.E.); christian.madu@unn.edu.ng (C.N.M.) \\ 2 Department of Civil Engineering, University of Nigeria, Nsukka 410001, Nigeria; \\ Jonah.agunwamba@unn.edu.ng \\ 3 Department of Management and Management Science, Lubin School of Business, Pace University, \\ New York, NY 10038, USA \\ * Correspondence: obiora.ezeudu.pg03150@unn.edu.ng; Tel.: +234-080-60828002
}

Received: 28 December 2018; Accepted: 3 March 2019; Published: 18 March 2019

\begin{abstract}
Paper as a consumer product offers a undisputed benefits to human society, and it has been proven to be critical in driving most sensitive needs of mankind-principally in areas of security, education, sanitation, and communication - and thus has been produced and consumed worldwide. Its sustainable production and usage is one topic that has featured prominently in many discussion fronts and more often than not ends with recommendations for an alternative source of raw material, improvement in production procedures, and ecological concerns. Paper use is an ecological concern that has triggered many paper intervention actions around the world such as the Paper Task Force in USA, Sustainable Paper Alliance in China, and Paper and Beyond in Europe. In Nigeria, however, challenges associated with paper production, consumption, and economic prospects have not been adequately tackled. This is conspicuously evident in the huge volume of paper products imported annually into the country as a result of unsustainable local production. The cumulative impact of these issues reflect negatively on the Nigeria's paper industry and spread indirectly to the entire country's economy in terms of high capital freight spent on importation, volatile product price, and loss of employment opportunities. This work sought to review the challenges and opportunities associated with raw material sources, energy and water consumption, environmental pollution, paper consumption, and disposal of used paper products in Nigeria. The current review also advocated for wastepaper as a variant of raw material with a sustainable potential.
\end{abstract}

Keywords: paper products; paper production; paper consumption; raw material; energy consumption; paper recycling; Nigerian paper industry

\section{Introduction}

Paper as a consumer product has proved critical in driving most sensitive needs of mankind, notably in areas of security, education, sanitation, and communication [1]. Paper was first developed in $105 \mathrm{AD}$ in China, and since then, its production and consumption have steadily increased. This is often attributed to two factors which are: (i) global socio-economic realities such as burgeoning world population, advancement in technology and global economic prosperity; and (ii) its physiochemical properties such as durability and flexibility that have made it possible for paper materials to be fashioned into variety of forms [2,3]. Hence, paper and paper materials have today become an indispensable component in almost all the finished consumer products in the market. Tissue papers used in the sanitation, cardboard paper used in electrical/electronic hardware, newsprint used for newspapers, sole inserts in the footwear, etc. are all common examples of paper applications. 
According to the Food and Agricultural Organization of the United Nations, the total gross value-added to national economies by the forestry sector is in tune of USD354 billion per year with the paper and pulp industry making the largest contribution amounting to half of the total figure. The total employment in the formal forestry sector reached 12.9 million in 2000, with the pulp and paper industry still contributing roughly $50 \%$ [4]. These statistics countered the emergent opinion of last four decades which predicted that the fortune of pulp and paper industry across the globe would upturn following the discovery of computers and other electronic devices [5]. The most cogent reason for this is what [2] described as the ability of paper material to compete successfully on a modern line, with other comparable products such as electronic information media, advanced plastic, and composite packaging materials. Nevertheless, the sectoral economic triumph has not in any way undermined the scientifically-proven challenges associated with paper consumption and production which borders on adverse environmental impacts, high energy and water consumption, and other cost variables. Therefore, there is an apparent need to achieve a balance between the economic growth and environmental protection. The advent of the sustainability concept has in turn created assessment methods, market-forces, and legislative practices to act as regulatory tools that would aid in ensuring ecological sustainability of production resources, production processes, and finished products and services [6]. The concept broadly crusade for certain ecological aspects to be considered while manufacturing a product such as selecting ecologically sound input materials, eco-friendly production processes, resource recovery, efficient recycling schemes, and ecologically-healthy waste management practices [7]. These instruments which have been clearly understood and judiciously applied widely across all industries are acknowledged as being the force behind the profitability and sustainability of pulp and paper industry in select countries of the world. However, in Nigeria, despite having vast human population and rich heritage of natural resources across its varied climatic belts, the stakeholders in the paper and pulp field are still yet to adopt these initiatives. The several formal and informal sectors pressing demands on paper and paper products across the country currently rely extensively on importation of both raw materials and finished products; which happens as a result of unsustainable local production. A prior attempt by federal government to manage its own integrated paper mills in Nigeria was unsuccessful. Factors that masterminded the dearth of these investments have been discussed in a number of studies [8-14]. The advances made generally in the global paper and pulp industry and its implication on Nigeria's paper industry which is old-fashioned was also studied by Ogunwusi and Ibrahim [9]. Thus the need to proffer solutions to the crisis that has engulfed the Nigerian paper industry motivated this study. The current work justifies why wastepaper should be accorded highest priority as a raw material feedstock for paper production in Nigeria. The review is unique as it studied in detail the challenges and opportunities facing the industry in Nigeria while quantifying by projections the potential of the so called waste paper stream from urban solid waste. It also appraised the nature of indigenous government policies as it concerns both raw material procurement and solid waste management and makes new recommendations with distinctive contextual conditions in Nigeria.

\section{Status of the Global Pulp and Paper Industry}

In the past, there was no common ground for reconciling environmental preservation and economic development [15]. The chaos gave rise to two schools of thought; with one advocating for caution and moderation on natural resource exploitation, while the other opined that economic pursuits should be absolute without attaching cost to environmental losses. However, world economic and development debates in the 1970s and 1980s led to invention of sustainability concepts to mediate the parallel interests with a call for striking a balance between the two ideologies. Environmental management tools such as cost benefit analysis (CBA) and risk analysis (RA) heralded the dialogue and have been used in analyzing the interplays between the development and environment. These earlier techniques could not satisfactorily execute the assessment task due to their limitations in assigning appropriate market values, underpricing, and shortchanging of parties involved. Scientific 
principles were later deployed and several other assessment methods were developed which include; material flow analysis (MFA), life cycle assessment (LCA), multi-criteria decision making (MCDA), environmental impact assessment (EIA), etc. Selecting by the scope, robustness, and frequency of application, LCA is a proven effective method for examining environmental performance side by side development undertakings. LCA as a tool is useful in assessing resources used and the potential environmental impact of a product or services throughout its lifetime, which is also known as 'cradle to grave'. It analyzes all the stages of a product's life cycle beginning from raw materials to manufacturing, transport, distribution, use, potential reuse or recycling, to final disposal. At each stage, the inputs (resources, energy, and raw materials) and outputs (solid wastes, air, land, and water pollution) are calculated and accounted for in an inventory-like manner [16].

The paper-making process is a unique developmental venture that could be evaluated against these tools [5]. Therefore, to gain better insight on the current and future sustainability of global pulp and paper industry, LCA concepts will be employed only to guide a review on the stages of acquisition of raw material, production processes, consumption, and disposal of end product.

\subsection{Acquisition of Raw Material}

Sourcing of virgin pulp for paper production begins with felling of trees. Existing data shows that, approximately 4 billion trees worldwide are lost annually to paper production, representing $35 \%$ in fraction of all harvested trees [17]. This figure is critical to deforestation and other severe environmental outcomes like drought and desertification. Deforestation alone contributes $25 \%$ of the annual carbon emissions caused by human activities as reported by [18] and has many determinants. The most common is incessant cutting of trees that has immediate repercussions such as wind and soil erosion and cumulative remote consequences such as desertification. The impact of these environmental hazards is notably visible in the Sahel regions of the world where the disaster has significantly cost several world bodies and governments financially at all levels in the name of ecological intervention funds. A type of cost that economists often argue to be undesirable on the grounds that preventive costs are better than remediation costs [19]. Unmitigated deforestation also has a cascade effect that eventually spins-off to global warming, melting of polar ice, sea level rise, climate change, extinction of plant and animal species, disruption of forests' natural duty of carbon bio sequestration, and destruction of useful land for agriculture. This list dominates the menu of the worst dreaded global environmental challenges and is part of the impetus for economic and development summits of Stockholm in 1972, Rio de Janerio in 1992, and Johannesburg in 2002. Unfortunately, to a greater extent, deforestation as a result of irrational harvesting of forest resources still persists around the world, especially at poor regions [20]. However, with growing effort towards replacing forest material with more eco-friendly and sustainable raw materials such as recyclable paper, non-wood fiber materials, and agro residues are positive initiatives continuously being adopted to counter ecological damage that comes with sourcing of forests' virgin pulp material for paper production. In the developed regions of the world, key players in pulp and wood business have moved commendably forward to the stage of harmonizing their production with reforestation, afforestation, and sustainable forestry. Global leaders in the sector like Georgia Pacific, Domtar, and International Paper are all American companies and they practice sustainable forestry [5]. On the other hand, in some global south countries like India, it is reported that only $49 \%$ of their mills run on forest-based pulp while mills that are solely contingent on agro-based residues and recycled fiber have risen to $29 \%$ and $22 \%$ respectively [21]. In Brazil, another developing location, the paper and pulp industry contributes greatly to their economy, it is equally disclosed that the utilization of recovered fiber for paper production in the country rose from 0.8 million tons/year in 1979 to 3.9 million tons/year in 2010 [22]. Within sub-Saharan Africa, South Africa could serve as an exemplary model for sustainable paper production. The Paper Manufacturers Association of South Africa reported in 2018 that the paper and pulp industry plants in excess of 210,000 trees, every single day, specifically for use in pulp and paper production. While about $65 \%$ of the country's paper mills depend on recycled fiber for production [23]. It is important to mention 
that reforestation for commercial and entrepreneurial possibilities has negative social impacts when evaluated against domination of arable land for agriculture, displacement of rural settlements which could induce rural-urban migration, and interruption of ecosystems for species threatened with extinction as well as wildlife. Environmental justice activists often maintain an aggressive stance on this. However, procedural environmental system assessment tools like social impact assessment (SIA) and CBA, have been quite useful in either designing alternatives or ameliorating associated adverse impacts of reforestation.

\subsection{Production Process}

The paper production process and other anthropogenic activities involves conversion of materials from their natural form to a more convenient state in order to satisfy man's needs. Apart from fiber, energy, water, and organic and inorganic chemicals are all major production logistics in the industry. The chemical-intensive nature of paper pulping and bleaching marks it as an unclean process that produces toxic waste products; and it has been judged as a major polluter of both the surface and underground water sources [1]. In the global industrial rating, the paper industry ranks fourth on the list of emitters of toxins to surface water sources, marking it a substantial contributor to environmental water pollution [18]. This could be considered unacceptable, especially in this contemporary era when the surge in human population has seen a rise in cumulative human water requirements, meaning that any attempt to compromise surface or underground water quality would be a serious threat to healthy living and aquatic terrestrial integrity. Treatment of effluents with pollution neutralizing facilities in various industrial activities-where high volume of chemicals, water, and other solvents are used-is continuously boosting efforts in recycling, reuse, and optimal conservation of water in industrial paper making [24].

In another direction, as global awareness is shifting towards efficient energy consumption, and the global pulp and paper industry being the fourth most energy-intensive manufacturing industry, a need exists for the sector to align with this worldwide vision $[1,18]$. This necessity is connected to the certainty that oil- and gas-based fuels constitute, in sum, $52 \%$ of the global primary energy consumption making it the most constantly sought for and utilized energy source by industries, despite having noted disadvantages of being non-renewable and finite in availability [25]. However, the future might not be entirely bleak, as progress is continually being made in the global drive for efficient energy consumption with International Energy Agency, reporting in 2016, a 12\% rise in world energy efficiency, amounting to savings of about 870 million barrels of oil, 205 million tons of coal, and 224 billion cubic meters of natural gas. The environmental offsets of these are encouraging which include reduction in greenhouse gases by 1.5 gigatonnes, a 13\% increase against 2015 figure [26]. In part, the pulp and paper industry has also documented a downward trend in energy use since 2000, with its highest share of $5.6 \%$ in global industrial energy consumption in 2014 [27]. This decline is in spite of the yearly growth in paper and paperboard production by $23 \%$ since the year 2000 . The most likely reason behind this reduction is that it is rapidly becoming a norm, especially in North America and Europe for paper mills, to use biomass residues (e.g., bark) to cover their energy needs [2]. Concurrently, continuous effort in harnessing and integration of renewable energy is given a redress to environmental impacts of fossil fuel exploitation and would in the long run be a sort of relief for mankind, as it makes energy utilization cheap and sustainable [28].

In addition to the overall effort to diminish the negative ecological influence that characterizes paper production; innovative developments in processing procedures such as organosolv pulping methods, total chlorine free bleaching, and use of nanotechnology are all being introduced [9]. Even down the paper supply chain, printing industry a major sub-sector player in paper production and consumption has equally recorded some improvements. Among the recent discoveries is ways of optimization of printing processes in order to ensure effective paper recycling. It has been demonstrated that with variations in printing techniques and optimal choice decisions on printing substrates, inks, preparation of printing forms, post printing and binding processes can be specified to enable full 
recycling of paper content without glue contamination [29-31]. Furthermore, changing of printing machine conditions with respect to voltage adjustments influences paper recycling efficiency [31].

\subsection{Consumption and Disposal of End Products}

Paper being a composite of fiber and chemicals is a precursor in that its by-products deserve an assiduous disposal approach [32,33]. Waste paper particularly can either be recycled, burnt, or buried. However, the pollution of ground water sources, landfill gas emissions, and increasing shortage of land space for landfills demerit burying whereas air pollution and loads of other health hazards that are linked to paper burning makes it likewise an objectionable option. Besides carbon emissions, other air pollutants are released from wastepaper burning in form of fine particulate matter, nitrogen, and sulfur oxides which are all detrimental to public health. The only viable alternative remains recycling. Detailed discussion on adverse impacts of wastepaper disposal methods can be found in $[1,4,5]$. Meanwhile, the growing public clamor for environmental quality has not in any way diluted the global paper consumption rate. In fact, over 300 million tons of papers are used globally in a year; a depiction that world consumption of paper has grown by 400 percent in the last 40 years [17]. Steady upswing in global consumption of paper is because of three reasons which include: (i) worldwide stretching population density which has its climax in developing countries where information technology facilities is still rarely easily accessible; (ii) paper and paper materials that have found wider application beyond office use; and (iii) consumer-based lifestyle that stimulates infinite quest and demand for finished goods. Today's overriding notion is that market-dynamics and legislative actions have readily become two regulatory media that have helped in ensuring ecological and economic sustainability of finished paper product [7]. It has subsequently triggered a new phenomenon regarded as 'economics of paper use', which prompts all paper users (buyers, sellers, suppliers, and producers) to analyze and consider the cost of producing fiber, recovering fiber from used paper product, and dynamics of market pricing of the various alternatives before arriving at a decision on producing, selling, purchasing, and consuming a paper product [24]. Although, it is important to mention here that, there are ultimate existence of economic and functional limits to the amount of recycled material that can be used in a paper on aggregate basis, but still on the scale of ecological preference, purchasing paper with recycled content provides comparative environmental benefits, in the areas of forest management, paper and pulp manufacturing, and solid waste processing and disposal [18].

Furthermore, analysis by the Environmental Paper Network (EPN), a global coalition of civil society organizations working together to achieve global paper vision, stated that world consumption of paper lately exceeded 400 million tons per year [1,34]. More than half of the consumptions occurred in America and Asia with further quarter in Europe, while the entire continent of Africa accounts for barely $2 \%$ of global paper consumption. The graphical depiction is as shown in Figure 1.

The report also showed uneven pattern in world's per capital consumption such that 7 of the 10 countries with the largest per capita paper consumption are in Europe. Whereas, the average per capita usage in China ( $76 \mathrm{~kg}$ ) alone is above the global per capita consumption of $55 \mathrm{~kg}$ [35]. The imbalance on consumption rate has induced new global focus and agitations which is positing that besides ensuring that paper usage does not cause environmental or social harm; equitable usage across the regions of the world is key to reducing unnecessary wastage since more paper usage ultimately leads to more waste. Equally proposed is that effort should be geared towards finding a way to assist societies below the paper poverty line of $30 \mathrm{~kg} /$ year stipulated by UNESCO, in meeting educational target [36]. 


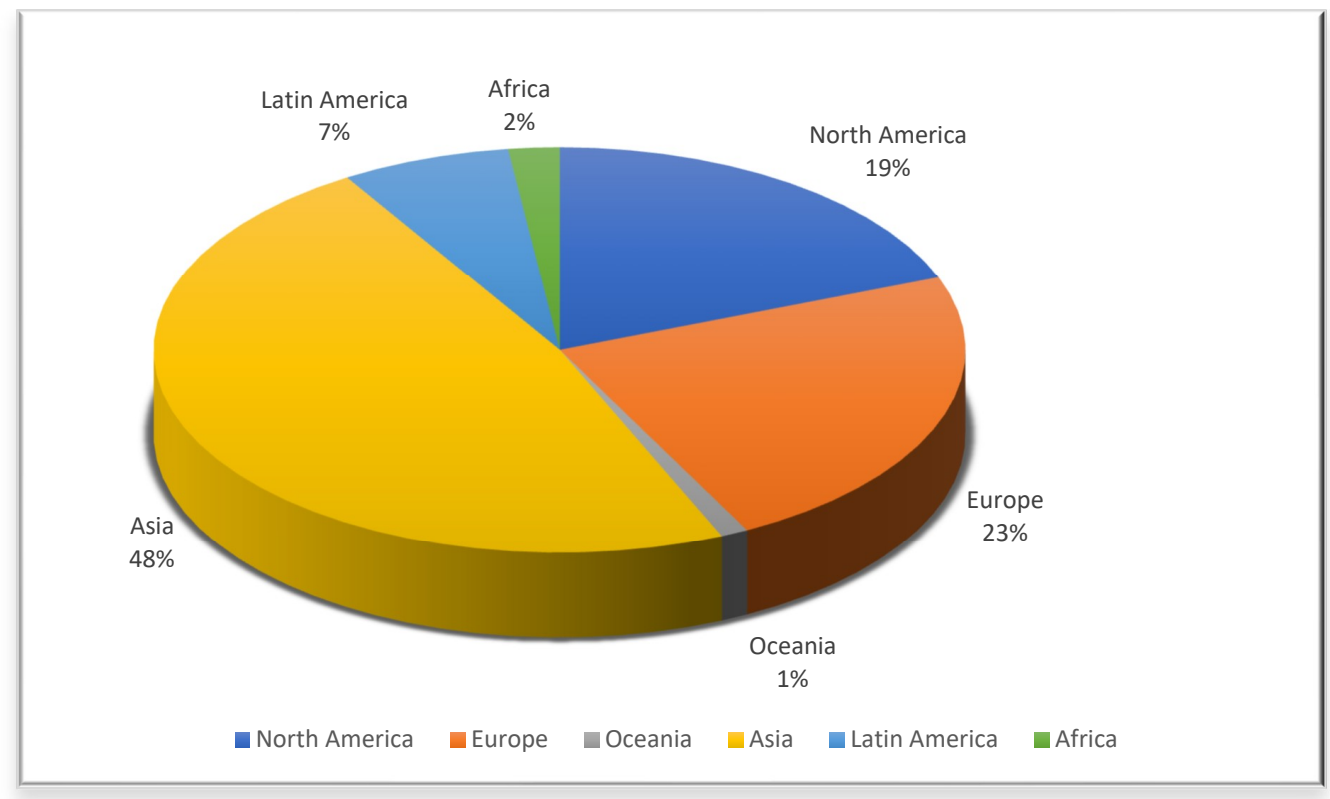

Figure 1. Global annual paper consumption by region. Data sourced from [34].

\section{Challenges and Opportunities Facing Nigerian Pulp and Paper Industry}

Nigeria, with a land area of approximately $924,000 \mathrm{Km}^{2}$, has a population estimated at 198,583,016 in 2017, calculated with 3.2\% annual population growth and based on 2006 census figure of $140.431790[37,38]$. Besides being richly endowed in crude oil and natural gas, Nigeria has an ample reserve of other solid minerals, vast and suitable land for agriculture, and water and forest resources. With non-inclusion of oil and gas industry that yields 95\% of the nation's merchandise earning, the other natural resource-based industries have experienced negative trade balances since 1980 [39]. For instance, Nigeria was Africa's largest wood producer, and a major exporter of timber resources, with industrial round wood export that was estimated in 1964 at 781,200 $\mathrm{m}^{3}$ with a net value of 36.10 million US dollars [4]. However, today the nation's forest industry-especially the paper sub-sector-seems to be the worst-performing among all the industries [40]. Three paper mills were established by federal government in 1970s which include-Nigerian Paper mill in Jebba, Nigeria Newsprint Manufacturing Company, Oku Iboku and Iwopin Pulp and Paper Company. Though they started well, but over time, they could not sustain operation and eventually closed down by 1996 [13,14]. Even after the companies were privatized in 2006, they still could not perform [12]. Studies done previously to find out the cause of the failed investments predominantly attributed it to absence of long fiber plant resources in the Nigerian forest, which necessitated outrageous dependency on imported pulp fiber and others alike. However, in the face of the abundance of favorable conditions for mechanized agriculture and sustainable forestry, it has been hinted by $[7,14]$ that (i) a comprehensive research on a particular plant species that could be used for sustainable forestry considering Nigeria's soil conditions would have been a way forward towards rectifying the anomaly. Some of the species mentioned in the study include-Pinus species, sterculia setigera, kenaf, sterculia oblonga; bamboo; Hibiscus cannabinus L. (ii) With expansive availability of agricultural residue in Nigeria, production of paper of pulp from these agro-wastes would equally be feasible. These suggestions were never adopted either in the short term or long term until the mills collapsed. The second factor fingered for the non-performance of the paper mills points to the fact that nearly all the chemicals and some other input resources required for paper making, none are produced domestically. This is a situation which has degenerated to the extent that, at the moment, only $5 \%$ of all the raw materials needed for making of paper in Nigeria are sourced locally [39]. The effect of these deficiencies are rightly reflected in import trade figures for paper and paperboard/art of paper pulp, paper and paperboard from 2010 to 2015 which was quoted at 658.1 billion naira, as seen in Table 1. These import trade 
sums are even higher than pharmaceutical products, beverages, spirits, and vinegar data added together. The net amount builds higher to 798.9 billion naira when aggregated together with values for printed books, newspaper, pictures, and other miscellaneous paper products. The successes of both Indian and South African paper industries as mentioned in the foregoing section, have been tipped to partially rub off on Nigeria's local paper production, as a substantial part of paper and paper products used in Nigeria come from these places. About \$66 million worth of paper and paperboard material were imported from India alone in 2017 [41]. The accrued consequences negatively mirrored on the nation's socio-economic indices in form of low GDP, high cost of paper product, pressure on capital freight and loss of employment. In exact terms, importation of paper and paper products in Nigeria is said to have compromised over 200,000 jobs that would have been available for young Nigerians [40]. In addition, the remnant of surviving local paper manufacturers are still contending with issues of obsolete equipment, inability to access funds and monumentally dilapidated public infrastructure $[9,12]$.

Table 1. Import of raw material and product in Nigeria from 2010-2015 (items below 1 trillion but above 100 billion naira). Source [39].

\begin{tabular}{cc}
\hline Commodity Description & Amount (Billion Naira) \\
\hline Sugar and Sugar Confectionery & 894.0 \\
Paper and Paperboard; Art of Paper Pulp, Paper/Paperboard & 658.1 \\
Miscellaneous Chemical Products & 451.1 \\
Aluminum and Articles thereof & 397.7 \\
Cocoa and Cocoa Preparations & 310.4 \\
Miscellaneous Edible Preparations & 305.7 \\
Pharmaceutical Products & 302.2 \\
Beverages, Spirits, and Vinegar & 286.6 \\
Animal/Vegetable Fats \& Oil and their Cleavage Products, etc. & 276.1 \\
Essential Oils and Resinoids, Perfume, Cosmetics/Toiletries & 259.9 \\
Ceramic Products & 245.6 \\
Tanning/Dyeing extract, Tannings and Derived Pigments, etc. & 239.2 \\
Tobacco and Manufactured Tobacco Substitutes & 164.4 \\
Printed Books, Newspaper, Pictures, and Other Products & 154.9 \\
Glass and Glassware & 140.8 \\
\hline
\end{tabular}

The worst affected among the poor public utilities in the country is water and energy supply [42,43]. Responsibility of providing these two essential needs in Nigeria for either industrial or domestic purposes is a survival burden taken up individually by all Nigerians. City inhabitants explore underground water sources such as wells, boreholes, and dams to meet their daily water needs due to non-existent or non-functional public water corporations in most of the urban areas of the country [43]. Consequently, little is known about the quality and quantity of water consumed or wasted by Nigerian industries [44]. Another contributing factor is poor or weaker regulation and enforcement by National Environmental Standard and Regulation Agency (NESRA) empowered by law to-regulate, monitor, and enforce-industrial water usage, effluent discharge limits, and other related functions. Even with the existence of laudable laws, implementation officers are few, far between, insufficiently trained, and many lack work incentives, motivating conditions, and professional monitoring facilities to be fully dedicated and effective in the task of enforcing these laws; thereby making it difficult in holistic term to collate or analyze environmental data [15].

The water supply inefficiencies share similarities with crisis in the energy sector where Nigerian government failed overtime to seize the opportunity advanced by huge availability of potential primary energy resources in its geographical landscape, to be a leading figure in grid-connected energy generation in sub-Saharan Africa [42]. The nation is currently plagued with energy starvation and deprivations with little or no hope of resolution in the nearest future [28]. The pessimism is premised on the existing reality that out of $6000 \mathrm{MW}$ electricity generation capacity installed in the country, 
only 1600 MW could still be generated; a figure below 2000 MW said to be needed by the Nigerian industrial sector alone as at 2009 [28,45]. Nigeria's current average electricity supply per capita of $160 \mathrm{kWh}$ is all time low and far behind the figure for Egypt and South Africa with $1776 \mathrm{kWh}$ and $5061 \mathrm{kWh}$, respectively [46]. These two nations are leading producers of pulp and paper in Africa. The total primary energy supply (TPES) for South Africa and Nigeria is not significantly different despite marginal disparity in their populations. Table 2 list data on the electric energy supply in the countries of Africa with the highest market share of pulp and paper production. From the table, it could be normal to infer that there is a significant correlation between the country's electric energy supply quantities and its paper production capacity. So to say, the poor energy supply condition in Nigeria is a barrier to attaining sustainable paper production. This is far from being good for a country whose population has been predicted to hit the 400 million mark by 2050 [47].

Table 2. Electric power supply in the countries of Africa with highest production of pulp and paper. Source $[46,48]$.

\begin{tabular}{ccccc}
\hline Country & TPES (PJ) & TPES (GJ/Capita) & $\begin{array}{c}\text { Electricity Supply } \\
(\mathbf{k W h} / \text { Capita) }\end{array}$ & $\begin{array}{c}\text { Market Share of Pulp \& Paper } \\
\text { Production in Africa as at 2015 (\%) }\end{array}$ \\
\hline Nigeria & 4733 & 29.9 & 160 & 3 \\
South Africa & 5730 & 114.3 & 5061 & 65 \\
Egypt & 3067 & 37.8 & 1776 & 20 \\
Tunisia & 403 & 38.5 & 1455 & 6 \\
Morocco & 691 & 21.6 & 837 & 4 \\
Algeria & 1690 & 47.7 & 1212 & 1 \\
Others & - & - & - & 1 \\
\hline
\end{tabular}

In any case, one critical factor that has ameliorated the misgivings of energy generation and supply in Nigeria is what [5] called 'frugal innovation'. A situation where lesser technologies are created to provide a much-needed services at a fraction of the cost of a traditional service. For example, because of the abysmal performance of electricity infrastructure in the country, many technology firms tend to create products such as miniature electric generators, solar panels amidst others, for personal and commercial use. This farther translates that every home, office, establishment and industry acquire so-called 'frugal technologies' according to their needs, capacity, and convenience. A situation that spells doom for the environment and public health in totality as quantification and regulation of emissions that emanate from these practices become practicably impossible. It also materializes in commerce and the whole economic system of Nigeria in the form of high costs of production which inversely multiply the final price of goods and services [28].

Despite these abnormalities, Nigeria enjoys respite in its thriving domestic market which is often regarded as an incentive for the emergence of a strong industrial base [39]. This is evidently obvious from the aforementioned trade import statistics for paper and paper products in the country. The public sector alone spends roughly 50 billion naira annually on purchase of paper and its allied products [49]. However, as the demand for paper and for paper material rises, the market in Nigeria would continue to grow, as in the case of soft tissue paper popularly known as 'toilet roll' in Nigeria. This paper product has been classified among the most profitable and fast-selling items in the country [50]. The paper variant is used in personal cleansing, sanitation, and hygiene, and is frequently demanded by offices, schools, hotels, restaurants, households, etc. as it comes in various forms such as serviettes, face towels, and kitchen towels. Demand and consumption for toilet rolls are likely to be aggravated by demography which revealed that more than half of the Nigerian population falls within the active age group (15-34 years); the majority of which are simultaneously categorized within the middle class [51,52]. These two classes of consumer populations are tied to high demand for hygiene and sanitation $[50,52]$. 


\section{Pattern of Production and Consumption of Local Goods in Nigeria}

Figure 2 shows the sectorial data of production and consumption of goods made in Nigeria. Overall, all the local industries received an incredible patronage for their products by local consumers. In amazement, articles of high cost values such as electronics and assembled motor vehicles were consumed in the rate they are produced [53]. Simply a fierce reaffirmation of previously mentioned fact that internal trade and domestic market in Nigeria is healthy and robust. From an econometric point of view, the picture portrayed could be likened to that of massive number of consumers yearning for unavailable local products but have resorted to imported commodities in order to douse their helplessness. A condition very conducive for prospective investors. On reassessment, also from Figure 2, paper industry displayed the lowest figures for production and consumption for local products among all the industrial divisions, placing the sector on the rank of likely lowest capital investment and output. The chief culprit could be deplorable performance of existing paper mills. On a second thought, it may have conveyed the unwillingness of indigenous people to invest in the paper business due to long perceptions hinging on the absence of raw pulp resources. However, a revelation made in the current study on massive availability of recyclable fiber resources is that the future might not be gloomy for potential investors. In general terms, it may equally be deduced that-in spite of the challenges discussed in regard to poor infrastructural facilities in Nigeria-compensating factors still exist for businessmen in the form of high product patronage and high sales turnover. It would also not be out of place to infer that the attitude of local consumers towards products made in Nigeria are positive and devoid of prejudice [54].

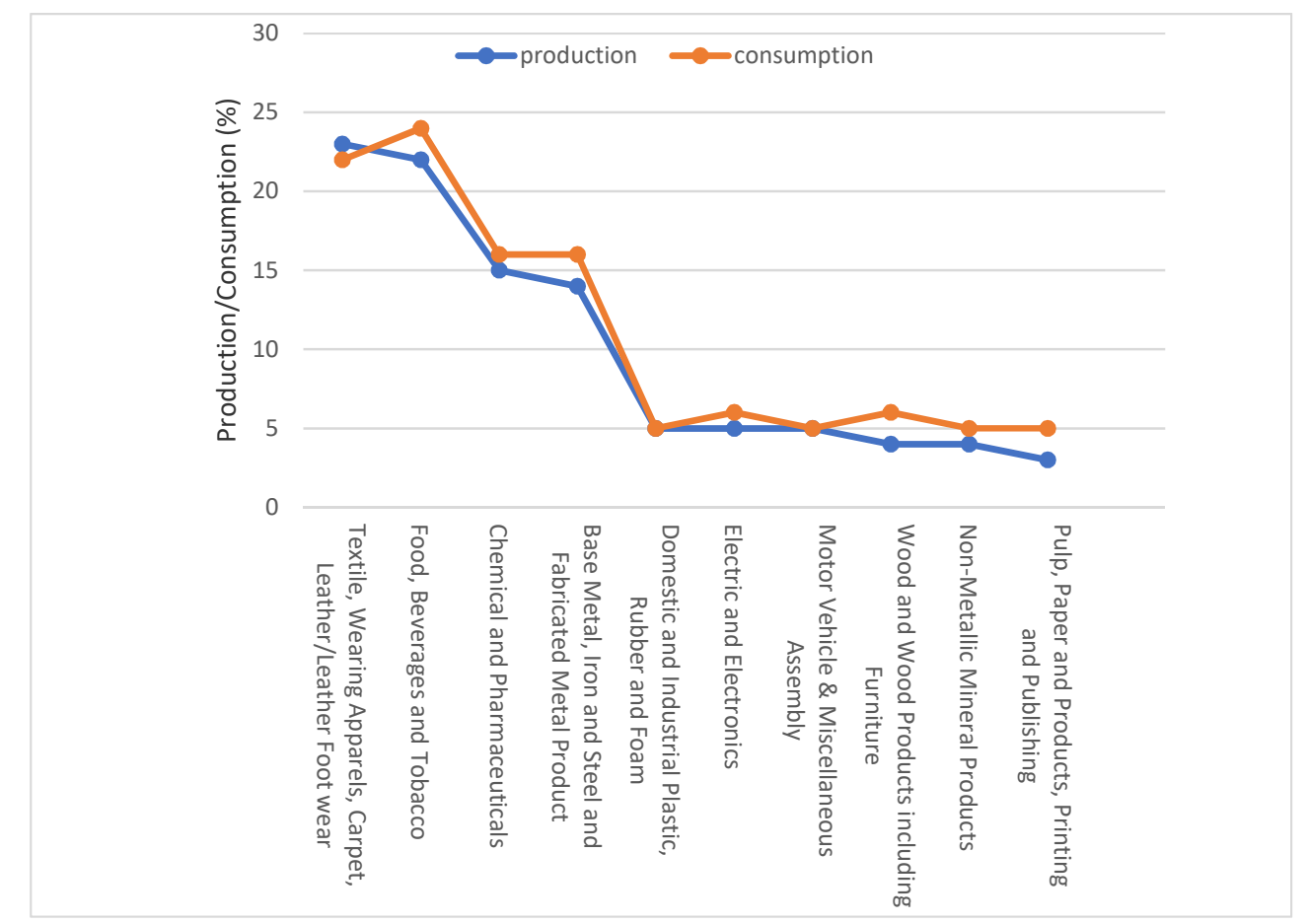

Figure 2. Current domestic sectorial production and consumption index in Nigeria. Data sourced from [39].

\section{Motivations for Rising Global Adoption of Paper Recycling}

Because of the structural peculiarity of urban cities that concentrates a large number of people in a localized area, the urban population in most places depends on importation of foodstuffs and other necessities of life from far distances to make up for supply from the countryside [55]. The city's environment, already choked with developmental activities, could not properly absorb, disperse, or dilute the generated waste resulting from the used products. The aftermath is that streets are endlessly flooded with waste which is now called 'urban solid waste'. Relying on over stressed 
damaging effects of poorly disposed wastes on human health, solid waste management has become one of key performance indicators of sustainable cities and societies $[16,56]$. It is often taken to be that cities that cannot effectively manage their solid waste are barely able to handle more complex services like health, education, and transportation [57]. On this basis, objectives of waste management quickly shift from collection, transportation, treatment, and outright disposal to prevention, minimization, reuse, recycling, and resource recovery from waste. Since many materials found in municipal solid waste are recyclable, a necessity has emerged for solid waste handling to operate on a precautionary principle, where conscious efforts are made by waste managers to extract maximum gains from the used products [58]. This is partly the stimulus for today's rising sensitization on recycling as a waste handling technique.

On the other hand, paper recycling — which ranks high in the wastepaper disposal alternatives-has received popular attention recently due to factors summarized by [59] as heightening public awareness on the environmental consequences of wastepaper disposal (burning and burying). More so, as a method of waste management, paper recycling could provide extra benefits in form of cost reduction, raw material conservation, pollution minimization, prevention of greenhouse gas emissions, job opportunities, and an avenue for development of clean technology mechanisms. Escalating global interest in waste paper as preferable raw material source for paper production, also stems from alarming ecological dangers that discredit production based on virgin pulp from forests [5]. Supplementary succor for the interest is the fact that paper waste is being generated daily and in consequential volumes across the cities of the world. In a highly industrialized nation like United States for instance, the quantity rate of paper waste generation has gone up from $33.5 \%$ in 1990 to $65.8 \%$ in 2017, and is even projected to hit $70 \%$ by 2020 [60]. By and large, success attained so far is that substitution of virgin fiber with secondary pulp as a feedstock for production of different classes of paper is helping in resolving problems of limited and fast depleting world forest reserves and climate change related issues $[5,7,18]$. Although, virgin pulp would still be needed in paper making as paper fibers shorten and weaken with each round of recycling [2].

Ecological economics also favors recycled fiber as raw material for paper making in two distinctive ways. First is, due to its ability to minimize water consumption. Paper made from $60 \%$ and $100 \%$ recycled fibers content conserves $35 \%$ and $47 \%$ of water respectively when compared to paper produced from $100 \%$ non-recycled fiber material $[5,9]$.

Second is that recycled fiber as raw material has proven ability to drastically reduce energy consumed by the paper and pulp industry. Conservative application of energy is essential due to the negative effects of the fossil fuel on the global environment which comes in form of air, water, and land pollution. Thus, in ensuring sustainability, there is a need for promoting industrial production practices with energy saving potential like recycling, which would contribute commensurately in curtailing harmful impact of rampantly used non-renewable energy sources on the environment. More benefit could accrue with elimination of wood logging activities from the production process. The breakdown of emissions, water, and energy reduction potentials of recycled fiber is shown in Table 3.

Table 3. Reduction in emissions, energy, and water consumption achieved by using recycled fiber. Source [9].

\begin{tabular}{cccc}
\hline $\begin{array}{c}\text { Savings in Input } \\
\text { Material/Emissions }\end{array}$ & $\begin{array}{c}\text { Paper with } \\
\text { Non-Recycled Paper }\end{array}$ & $\begin{array}{c}\text { Paper with 60\% Recycled } \\
\text { Fiber (MS Green Range) }\end{array}$ & $\begin{array}{c}\text { Papers with 100\% Recycled } \\
\text { Fiber (Cyclus Range) }\end{array}$ \\
\hline Water conserved & $0 \%$ & $35 \%$ & $47 \%$ \\
Potential energy saved & $0 \%$ & $20 \%$ & $80 \%$ \\
GHG emissions reduced & $0 \%$ & $55 \%$ & $80 \%$ \\
\hline
\end{tabular}

Furthermore, many market instruments emanating from Multilateral Environmental Agreements (MEAs) are being employed to reduce emission and carbon footprints such as carbon finance; carbon credit, which means a permit representing the right to emit one ton of $\mathrm{CO}_{2}$ or quantity of another GHG equivalent to one ton of $\mathrm{CO}_{2}$; and carbon market, where emissions are traded with the aid of these instruments in manner analogous to conventional stock market. All these market tools have a clear 
mission of keeping clean manufacturers like paper recyclers at trade advantage in the carbon market. Clean development mechanism (CDM), another provision of the Kyoto Protocol, has enabled buyers from developed countries to purchase greenhouse gas emission reduction projects in developing countries [61]. The World Bank, who act as a trustee for these funds, has financed projects in tune of millions of dollars. With the Bank recently widening their project scope to accommodate recycling, active and strategic participation in the CDM's paper recycling project would be a channel for the low income countries to earn a tangible foreign exchange.

\section{Methods and Materials}

Internet sources were searched for matching literature on two distinctive subject matters which are 'paper production in Nigeria' and 'municipal solid waste management'. The key words for the search include but not limited to waste characterization, paper recycling, Nigerian paper mills, and paper waste. Some further materials were identified through reference list of these publications. The first category of the selected literatures were reviewed, from which the established findings readily indicated polluting production; issues of raw material, energy, and water shortages; and volatility in pricing of finished paper and paper products sanctioned by raw material importation. These findings suggest that paper recycling in Nigeria is a non-negotiable option for sustainable paper production (see Supplementary Material for references list). While the gap in literation lies on the fact that none among the studies have analyzed these challenges in one with the aim of recommending solutions. The second batch of literature on waste management was selected to review the current waste handling practices and policies, and also to select studies suitable for the proposed theoretical projection of waste paper potential in Nigeria (see [15,62-69]). As a matter of fact, none of the reviews done in the past at few city locations in Nigeria on characterization of municipal solid waste have failed to highlight a significant presence of recyclable paper waste stream (see [38,63,70-75]). On account of this, estimations are made in this study to provide an insight into the abundance of this resources that could serve as raw material for paper production.

\section{Results and Discussion}

\section{Projections of Waste Paper Generation and Collection Rate}

The current waste paper generation estimate would be made for 2018 and projected further to 2025, although many parameters influence the quantity of waste generation in cities. However, the most accepted general factors sensitive to making projections are; the city's population, population growth index, and per capita waste generation [70].

Adopting the 2006 population census figure, $\boldsymbol{P}_{2006}$ of $140,431,790$ and annual population growth, rate $r$ of $3.2 \%$ [37]. Projected total Nigeria's population for future year 20XY would be

$$
\boldsymbol{P}_{20 X Y}=P_{2006}(1+r / 100)^{20 X Y-2006}
$$

which gives 204,937,672 for 2018 and 255,493,396 for 2025. If we assume current Nigeria's urban population of $48.6 \%$ to remain constant [76]. The urban population for future year would be

$$
\boldsymbol{P}_{20 X Y(\text { urban })}=0.486 \times \boldsymbol{P}_{20 X Y}
$$

Assuming $\mathrm{Q}_{20 \mathrm{XY}}=$ per capita waste generation for future year, and considering that Nigeria is categorized as low medium income, where $9 \%$ of the total urban waste is paper and would increase to $10 \%$ by 2025 [57]. The per capita waste generation rate of 0.63 would be used, a value from [71] as is the most current study done as shown in Table 4.

The total quantity of urban waste generated in Nigeria for future year would be

$$
\boldsymbol{q}_{20 \mathrm{XY}}=0.63 \times \boldsymbol{P}_{20 \mathrm{XY}(\mathrm{urban})}
$$


While the corresponding total urban paper waste for future year would be

$$
\boldsymbol{P}_{\mathrm{w}}=0.09 \times \boldsymbol{q}_{20 \mathrm{XY}}\left(\text { before 2025); } 0.1 \times \boldsymbol{q}_{2025} \text { (for 2025) and } 0.1 \times \boldsymbol{q}_{20 \mathrm{XY}}(\text { for beyond 2025) }\right.
$$

Since $75 \%$ of urban waste in Nigeria is assumed to come from households [38]. The quantity of the urban waste that is generated in Nigeria by households alone for future year is given by

$$
H w=0.75 \times q_{20 X Y}
$$

and quantities of paper waste from households would be

$$
H_{p w w}=0.0675 \times \boldsymbol{q}_{20 X Y}\left(\text { before 2025); } 0.075 \times \boldsymbol{q}_{20 X Y}\left(\text { for 2025) and } 0.075 \times \boldsymbol{q}_{20 X Y} \text { (for beyond 2025) } .\right.\right.
$$

when considering that only $41 \%$ of the waste is collected in 2018 and about $60 \%$ by 2025 [57], the urban paper waste collection rate becomes 5.65 million tons/annum and 7.04 million tons/annum for 2018 and 2025 respectively. The figures for the years in between are shown in the Table 5. However, a sizeable proportion of the Nigerian population have limited or no access to waste management services, so waste collection rates are far behind the generation rate [77]. As can also be seen from the Table 5, there are significant differences between waste generated and the amounts practically collected, a typical condition common to all low income countries. The main causes of this are; poor financial resources, limited technical capacity, lack or inadequate enforcement of environmental laws, poor awareness campaigning, and poor infrastructure [46]. Also, the theoretically-calculated potential was done based on waste collected from urban cities, the extension of waste management schemes to rural areas could positively influence the scenario, to add considerable volume of waste paper stream for paper recycling industry. Waste stream compositions of low income countries are usually dominated by organic waste, while high income countries are known for producing more inorganic (inert) waste like paper, plastic, ceramics, etc. [78,79]. This trend would likely change in the future as Nigeria struggles to move to the high income league of nations.

Table 4. Generation rate of paper waste in select cities of Nigeria.

\begin{tabular}{|c|c|c|c|c|c|c|c|c|}
\hline $\begin{array}{l}\text { Year } \\
2018\end{array}$ & $\begin{array}{c}\begin{array}{c}\text { Total } \\
\text { Population } \\
\text { (million) }\end{array} \\
204.938\end{array}$ & $\begin{array}{c}\begin{array}{c}\text { Urban } \\
\text { Population } \\
\text { (million) }\end{array} \\
99.60\end{array}$ & \multicolumn{2}{|c|}{$\begin{array}{l}\text { Total Urban Waste } \\
\text { Generated/Collected } \\
\text { (million tons/year) }\end{array}$} & \multicolumn{2}{|c|}{$\begin{array}{l}\text { Total Paper Waste } \\
\text { Generated/Collected } \\
\text { (million tons/year) }\end{array}$} & \multicolumn{2}{|c|}{$\begin{array}{c}\text { Total Paper Waste } \\
\text { Generated/Collected by } \\
\text { Household (million tons/year) }\end{array}$} \\
\hline 2019 & 211.496 & 102.79 & 64.76 & 26.55 & 5.83 & 2.39 & 4.37 & 1.79 \\
\hline 2020 & 218.264 & 106.08 & 66.83 & 27.40 & 6.01 & 2.46 & 4.51 & 1.85 \\
\hline 2021 & 225.248 & 109.47 & 68.97 & 28.28 & 6.20 & 2.54 & 4.65 & 1.91 \\
\hline 2024 & 247.571 & 120.32 & 75.80 & 31.08 & 6.82 & 2.80 & 5.12 & 2.10 \\
\hline 2025 & 255.493 & 124.17 & 78.23 & 46.94 & 7.04 & 4.22 & 5.28 & 3.17 \\
\hline
\end{tabular}

\begin{tabular}{ccccc}
\hline Reference & City Studied & Year of Study & $\begin{array}{c}\text { Quantity of Paper } \\
\text { Waste (\%) }\end{array}$ & $\begin{array}{c}\text { Per Capita Waste } \\
\text { Generation (kg/capita/day) }\end{array}$ \\
\hline$[72],[71]$ & Abuja & 2006,2013 & $(6.9-13.0), 9.7$ & $(0.54-0.58), 0.63$ \\
{$[63]$} & Nsukka & 2003 & 13.8 & 0.44 \\
{$[73]$} & Lagos & 1982 & 14.0 & 0.63 \\
{$[70]$} & Makurdi & 2007 & 12.6 & 0.54 \\
{$[74]$} & Kano & 1982 & 17.0 & 0.56 \\
{$[74]$} & Onitsha & 1998 & 23.1 & 0.53 \\
{$[74]$} & Ibadan & 1985 & 6.6 & 0.51 \\
{$[74]$} & Maiduguri & 2003 & 7.5 & - \\
{$[75]$} & Ogbomosho & 2007 & 16.6 & 0.13 \\
\hline
\end{tabular}

Table 5. Projected quantities of waste paper generation and collection for Nigeria. 
As a result of changing global urban lifestyle, the amount of municipal solid waste in cities is growing rapidly, exceeding the rate of urbanization itself [57]. This correlates the fact that today's 3 billion urban residents currently generate 1.3 billion tons of solid waste per year at the rate of $1.2 \mathrm{~kg} /$ person/day as against 0.68 billion tons/year generated at the rate of $0.64 \mathrm{~kg}$, a decade before now [16,57]. Moreover, by 2025, number of people living in urban cities is likely to increase to 4.3 billion and would be generating 2.2 billion tons of waste per year at the increased rate of 1.42/capita/day [16]. In agitation, the municipalities and urban cities have grown rapidly with the pace of urbanization in Nigeria showing extraordinary high rate of 5-10\% per annum on average [80]. Nigeria's urban population grew from 3.5 million people in 1950 to 68 million in 2010 and is projected to hit 287 million by 2050 [81]. As of 1995, Nigeria had barely 7 cities with a population of over 1 million; 18 cities had more than 500,000 people; 36 with over 200,000; and 78 with more than 100,000. By, 2020 it is expected that the cities with populations of 500,000 and 200,000 respectively will be 36 and 680 respectively, assuming an annual urban growth rate of $5 \%$ [82].

Over the decades, the population of major Nigerian cities has increased in marginal proportion. Kano, Port-Harcourt, Ilorin, Maiduguri, and Jos all increased greatly in population since 1970. Kano's city population in particular rose from 2,095,000 in 1990 to 3,221,000 in 2010. Enugu with 159,000 people in 1970 and 363,000 people in 1990, will have, 1,085,000 in 2030. While over the same period, Lagos city with a population of below one million in 1964, jump to over four million in 1991 and then close to 10 million in 2006 [81]. Nigeria's 1950 population figure shows that, only $10.1 \%$ of population was urban. The figure rose to $20.10 \%$ by 1970 and is expected to hit $58.3 \%$ by 2020 [82]. Figure 3 shows the growth pattern of some cities in Nigeria while Figure 4 shows the similarities in the growth of the overall Nigeria's population and urban population. In consonance with the high rate of urbanization, the solid waste generation in Nigeria's urban area would continue to increase, probably a pointer that waste paper generation would rise. Other general factors that would influence high waste paper generation in Nigeria include continuous expansion in the education sector, increasing political and religious activities, submission of hard copies of projects, assignments, and proposals in schools and many more factors [83].

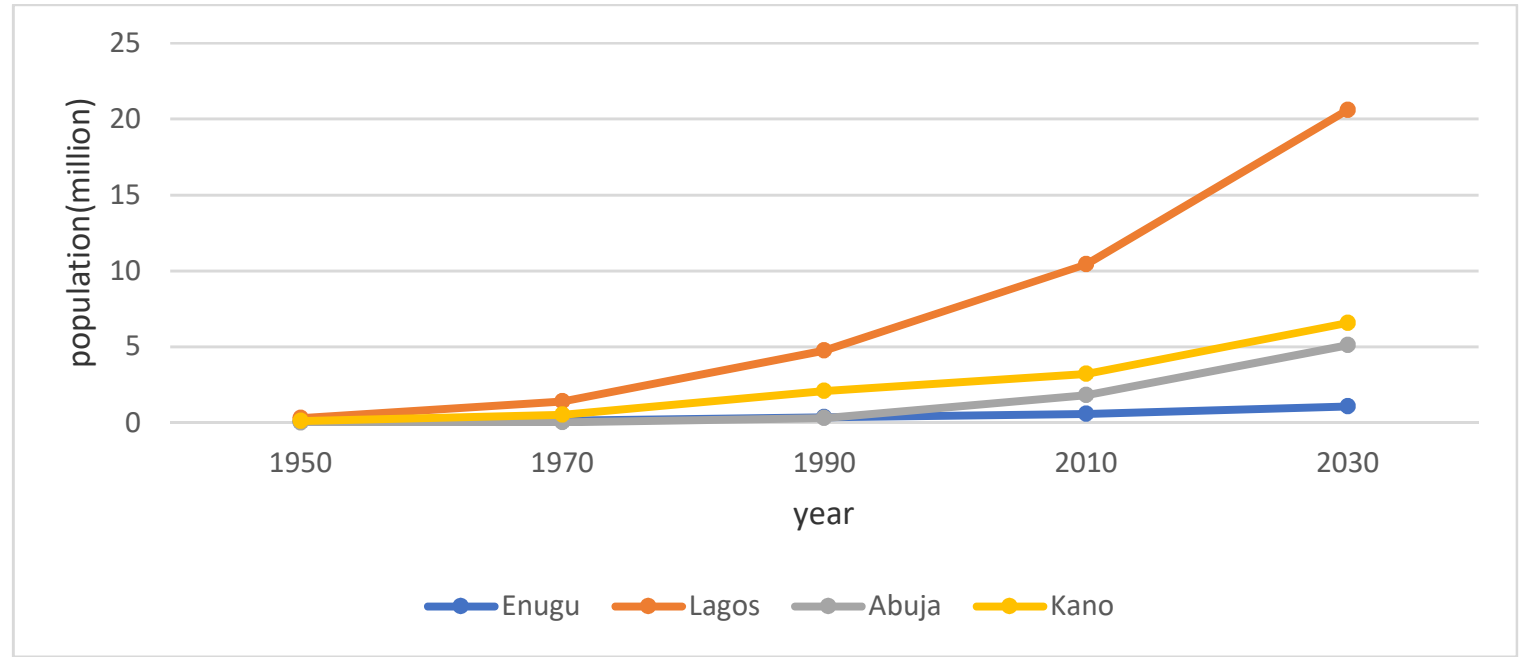

Figure 3. Growth pattern of some major cities in Nigeria. Source [81]. 


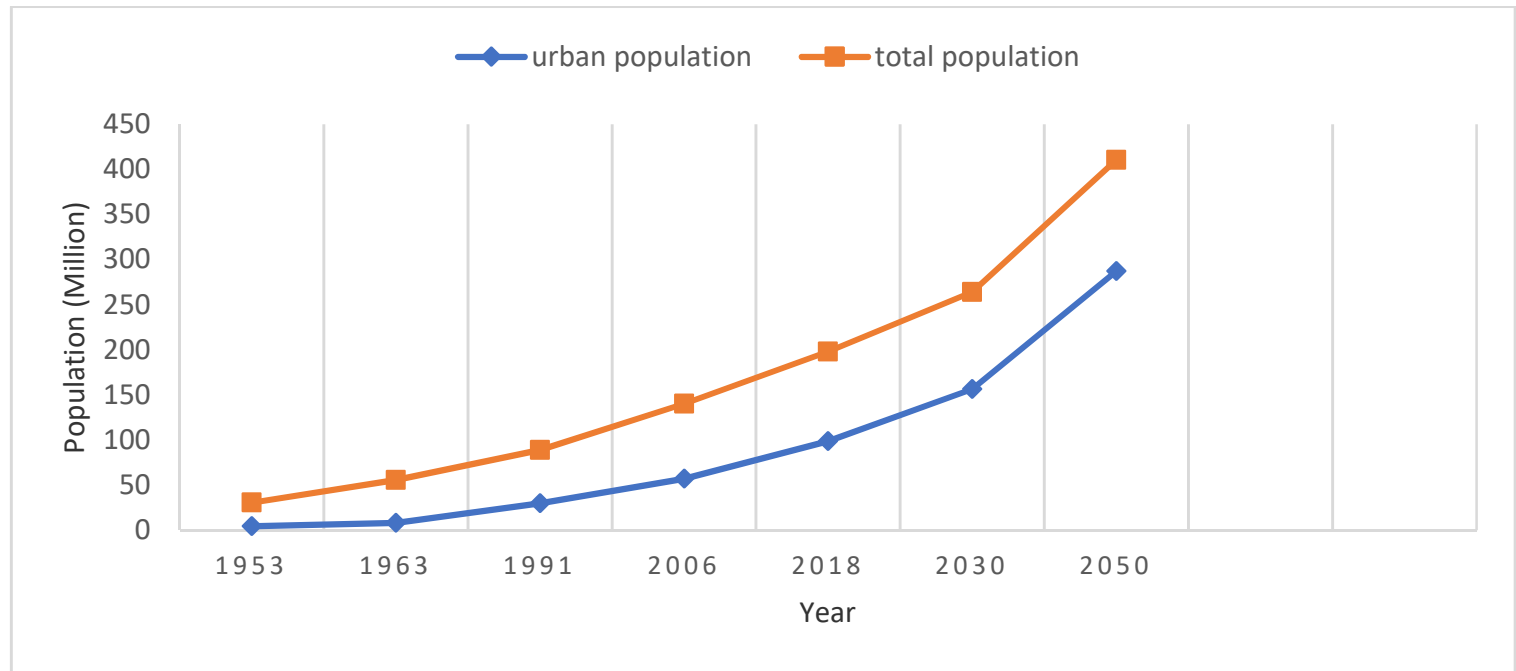

Figure 4. Total population growth rate of Nigeria's vs. urban population growth rate. Source [81].

\section{Government Policies on Raw Material and Solid Waste Management in Nigeria}

\subsection{Solid Waste Management Practices and Policy Landscape in Nigeria}

Discussing the waste management practices and policies in Nigeria on this study becomes imperative because of lack of dichotomy between waste paper as a mix in urban waste and as a raw material for paper production. In view of this, Section 20 of the 1999 constitution of Nigerian republic empowered the state governments under Federal Environmental Protection Agency (FEPA) Act of 1988, to make policies and guidelines on solid waste management as it pertains to their priorities and cases [84]. Critical perusal of these indigenous policies and guidelines against the international best practices as formulated by the Collaborative Working Group in Solid Waste Management in Low and Middle-Income Countries, will ascertain its suitability and functionality in promoting recovery of waste paper and other recyclables [85]. The elements, barriers, and recommendations are discussed in what follows;

(i) Recycling doubles as a waste handling technique and acceptable method for retrieving value from waste [64]. In third-world countries, it is an activity mostly practiced by poor people and often labelled informal activities or 'informal sector', which has reiterated a universal viewpoint that the environment matters most to people living in poverty. This is in two ways; the first is that they are more vulnerable to environmental externalities such as floods and droughts, and the second is that they assert high direct dependence on environmental resources [86]. Informal waste picking and sorting by scavengers has been recognized as a prime contributor to urban development averse to social stigma it was formerly associated with [87]. On this background, these activities have been going on in orderly manner, often with legislative backing in some developing countries like India and Colombia [88-90]. However, it is still neither coordinated nor regulated in Nigeria [65]. An issue exacerbated by the fact that the Federal Ministry of Environment's policy guideline on solid waste management released in 2005, dwelled on waste storage, evacuation, and disposal; but with no communication in clear terms, either by edict or regulation, on how waste recycling and resource recovery should be tackled [84]. Recycling is therefore left entirely as a voluntary waste management practice in Nigeria [64]. Against these odds, the informal waste recycling sector in Nigeria has created a worthwhile market segment and also yielded employment opportunities [65]. The operational system comprises of scavengers (as sellers), dealers (whose role is to mop-up buying from scavengers), and small and medium scale industries that finally use the recyclables. It has also given rise to small associations and unions in places like Abuja. In other locations like Lagos they have come together to register and operate a cooperative in order to have better bargains and stop middlemen from exploiting them [66]. However, the notable associations are the ones that deal mainly in metal scraps, plastic 
waste, and electronic waste. It appears that no known union or association seems to exist for paper recyclers in Nigeria.

(ii) Waste management as it is being presently practiced in Nigeria, has no platform for encouraging social acceptability through greater public participation. The involvement of public in waste management in Nigeria is barely rudimentary or voluntary as mentioned in the case of recyclers. Apart from National Sanitation Day that is usually marked on every last Saturday of the month in almost all the states of the federation, during which households are to remain at their homes between 7:00 a.m. and 10:00 a.m. to partake in cleaning their surroundings. Practices like sorting of waste from generation units and sources (households, commercial areas, institutions, etc.) is not compulsory and therefore not enforceable by law [67]. In the same manner, burning and burying of waste at homes, roadsides, and premises are still a common practice in Nigeria due to a lack of proper framework for enforcing environmental laws [68].

(iii) The waste policy landscape in Nigeria does not create a market-oriented approach for solid waste that would have provided economic efficiency by regarding waste products as a resources which could promote ties between sellers and buyers. A clear attestation of this is apparent in that majority of Nigerians are yet to contemplate waste as a means of wealth creation, but rather think of it as all rubbish that is meant to be discarded [64]. The outcome is that paper wastes of different grades are illicitly mixed up with biodegradable organic matter in various open dumps spread all over the country [69]. Uncontrolled decomposition of biomass that takes place at this dump sites contributes immensely to the greenhouse gas emissions and the carbon footprint of the country. It reduces the environmental aesthetic value and quality; becomes a breeding hood for rodents and other disease carrying vectors and pathogens, which invariably increases morbidity and adversely impacts public health at large [91].

(iv) The legislative foundations are weak in that they failed to make provision for upgrading to good waste handling options for all material within the stream of collected waste. Even where it does, there is no provision for sustaining it. For instance, Lagos Waste Management Authority (LAWMA) — a statutory body responsible for management of solid waste in the Lagos state-made attempts in the past to improve the waste management methods in the city through waste characterization, improved technology, and by partnering with private investors and foreign nations. The new initiatives though successful initially could not endure, because existing environmental laws did not make provisions for their long term sustenance. Ageing equipment, interrupted funding, and shortage of landfill spaces choked the program off [92].

(v) Onset articulation and planning to generate less waste by integrating urban planning with waste generation is not extensively embraced throughout the country. The practice is active only in the Abuja, Nigeria's capital city, where relevant permits are required by the provision of Abuja Environmental Protection Act (Solid Waste Control/Environmental Monitoring Regulations 2005) prior to any project execution. It is required by law for all proponents of major projects within the capital city to submit to the Abuja Environmental Protection Board, a detailed proposal containing the nature and scope of the project together with the location and address. Also to be submitted are the details of the activities to be carried on and other relevant information. The proposal would be subjected to scrutiny before decision would be made [93]. It has helped in fostering orderly planning of waste management schemes in the city and optimal resource allocation. On this note, it is our opinion that the entire state of the federation should adopt this guideline for integrated solid waste management that would facilitate maximum collection of paper waste component of municipal solid waste for paper production in the country.

\subsection{Appraisal of Raw Material Policies in Nigeria in the Context of the Paper and Pulp Industry}

The report on National strategy for competitiveness in raw material and product in Nigeria produced in 2016 by Raw Material and Research Development Council (RMRDC) with contributions from stakeholders-like the Manufacturers Association of Nigeria (MAN); and the Nigerian Association of Chamber of Commerce, Industry, Mine and Agriculture (NACCIMA)—outlined various 
recommendations for sourcing of local raw material for industries and businesses in Nigeria. The full report is in [39]. Surprisingly, in the section for paper, pulp, and printing, the report failed to earmark emphatic devotion towards recovering fiber from used papers, despite having been disclosed earlier on a separate survey on demand and supply on major raw material required in pulp and paper industry as seen Table 6, that only waste paper was close to meeting the targeted national demand by $74 \%$, whereas the rest of raw materials-long fiber pulp, short paper pulp, kraft paper, fluting paper, and newsprint - are all at nil dispatch in meeting the allocated demand [83]. Thereby securing a place for waste paper as the only promising raw material source capable of sustaining domestic production. The view may have also been conveyed that the government research did not explore this option.

Table 6. Domestic production and demand of raw materials required in paper and pulp industry in Nigeria in 2005. Source [12,83].

\begin{tabular}{cccccc}
\hline Raw Material & $\begin{array}{c}\text { Domestic } \\
\text { Production (tons) }\end{array}$ & $\begin{array}{c}\text { Domestic } \\
\text { Demand (tons) }\end{array}$ & $\begin{array}{c}\text { Supply Gap } \\
\text { (\%) }\end{array}$ & $\begin{array}{c}\text { Installed Capacity of } \\
\text { Nigeria Paper Mill } \\
\text { Jebba (tons) }\end{array}$ & $\begin{array}{c}\text { Actual Production of } \\
\text { Nigeria Paper Mill } \\
\text { Jebba as of 2009 (tons) }\end{array}$ \\
\hline Long Fiber Pulp (BDMT) & 0 & 85.668 .1 & 100 & 75,250 & 0 \\
Short Fiber Pulp (BDMT) & 0 & 280,000 & 100 & 280,000 & 125,000 \\
Waste Paper & 74,000 & 100.000 & 26 & - & - \\
Kraft Paper & 0 & 80,000 & 100 & - & - \\
Fluting Paper & 0 & 20,000 & 100 & - & - \\
Newsprint & 0 & 250,000 & 100 & - & - \\
Sodium Sulphate & 0 & 2600 & 100 & - \\
Sodium Ash & 0 & 55 & 100 & 100 & - \\
Sodium Hydroxide & 0 & 144,260 & 100 & - \\
\hline
\end{tabular}

Other good recommendations were suggested which include-long-term effort to cultivate long fiber plant species; participation of private investors that bought the privatized paper mills in raw material development efforts; use of non-wood fibrous plant and agricultural residue for paper production on the short-term and funding of market-oriented research and industrial development. Also from the report, the high demand of paper product in the country, was partly credited to Universal Basic Education (UBE) scheme embarked on by Federal Government with the mission of alleviating the illiteracy level among Nigerians. This project has occasioned substantial public sector spending on educational books such as notebooks, textbooks, etc. [39]. The loophole here is that the UBE policy designers failed to factor in anticipated high volume of waste paper that it is mostly likely to be generated from the program. Thus, it would have been an opportunity to integrate paper waste collection and recycling through the participating schools. In the RMRDC implementation plan published in a separate report released in 2017 see [53], waste paper contribution as a substitute for forest material was also not given a supposed recognition (Table 7). The targets set at 10\% in short-term $(0<5$ years), 35\% in medium-term, and 65\% in the long-term are ridiculous and probably not based on realities on the ground. It simply displayed either utter negligence or an attempt to underutilize these vast resources in Nigeria by stakeholders and policy officials. It is also our belief that projections made in this review would be an eye opener to the relevant authorities on the enormous contributions that waste paper derivative of municipal solid waste would make in driving paper recycling revolution in Nigeria. 
Table 7. Potential target on raw material and product Import reduction by RMRDC. Source [53].

\begin{tabular}{|c|c|c|c|c|}
\hline HS Code & $\begin{array}{c}\text { Broad Category of Raw Material } \\
\text { and Product }\end{array}$ & $\begin{array}{c}\text { Short-Term. } \\
0<5 \text { Years }(\%)\end{array}$ & $\begin{array}{l}\text { Medium-Term. } \\
5<10 \text { Years }(\%)\end{array}$ & $\begin{array}{l}\text { Long-Term. } \\
10 \text { Years and over }(\%)\end{array}$ \\
\hline 44 & Wood \& Articles of Wood; Charcoal Wood & 10 & 40 & 75 \\
\hline 45 & Cork \& Articles of Cork & 5 & 25 & 40 \\
\hline 46 & Straw, Esparto \& Other Plaiting Mat, etc. & 5 & 35 & 45 \\
\hline$(44-46)$ & $\begin{array}{l}\text { Wood \& Articles of Wood; Charcoal } \\
\text { Wood (Total) }\end{array}$ & 20 & 100 & 160 \\
\hline 47 & $\begin{array}{l}\text { Pulp of Wood/Other Fibrous Cellulosic } \\
\text { Mat; Waste, etc. }\end{array}$ & 10 & 35 & 65 \\
\hline 48 & $\begin{array}{c}\text { Paper and Paperboard, Art of Paper Pulp, } \\
\text { Paper/Paperboard }\end{array}$ & 5 & 30 & 50 \\
\hline 49 & $\begin{array}{c}\text { Printed Books, Newspaper, Pictures and } \\
\text { Other Products, etc. }\end{array}$ & 10 & 35 & 65 \\
\hline$(47-49)$ & $\begin{array}{c}\text { Pulp of Wood/Other Fibrous Cellulosic } \\
\text { Mat, Waste, etc. (Total) }\end{array}$ & 20 & 90 & 155 \\
\hline
\end{tabular}

\section{Further Recommendations}

Nigeria at present is a wood-fiber deficit nation [3]. Sustainable paper recycling practices, which are an option capable of resuscitating the unhealthy pulp and paper industry, are also in distress due to gross neglect from both official and unofficial circles. It is essential therefore that adequate measures should be taken to address these setbacks in order to make the sector more effective. To this end, a number of recommendations are made in this paper. First is that global state-of-the-art paper production is still dependent on both primary and secondary fiber resources, since the quality and strength of finished paper product is largely a result of good mixture of the two fiber sources. In essence, sustainable paper production in Nigeria can only be achievable by solving the over emphasized problems of unavailability of primary fiber material and also by making effort towards secondary fiber recovery. A typical example is Nigeria Paper Mill that, as of 2009, was producing a high volume of kraft paper solely from recycled pulp. However, due to poor load bearing capacity of the products that makes it hardly suitable for packaging, it was difficult for it to compete favorably with other high quality products that flooded the market through importation [12]. Limited accessibility and unstable forex rate obviously made the importation of virgin pulp an additional constraint for the company. It is the authors' recommendation that for the local paper companies to survive and thrive, there should be a special provision by the government to subsidize the forex rate for paper companies in the short run while multi-sector involvement in developing sustainable forestry across the country should be planned for the long term. The success of the sustainable forestry would eventually determine the rate and manner at which import tariffs would further be used to reduce paper products importation with the aim of promoting local production. Second is to recognize the importance of recycling as a sustainable waste management procedure and also as a means of wealth creation by all concerned [87]. One way to do this is by creation of paper recyclers association of Nigeria to act as a professional forum where waste paper recycling professionals and practitioners both in the public and private sector all over the country would meet yearly, as the case may be, to discuss paper recycling issues. The body would work for involvement of professional in promotions and setting policy guideline for paper recycling in Nigeria, at the same time serve as advisory body for appropriate government agencies. Paper Recycling Association of South Africa (PRASA), for instance, is a member of the Recovery Action Group (RAG), which is an umbrella body of all recyclers in the country. PRASA represents the interest of paper recyclers in RAG and ensures effective communication between industry and all level of governments [94].

Sustainable development of a nation is dependent on the policy, institutions, and legislative framework related to the environment as well as on the implementation capacity of such planning [80]. Considering the high volume of paper consumed in the country by both formal and informal sectors, modalities should be set on course to ensure optimal recovery of the resultant waste for onward recycling. Reverse logistic models in supply-chain management have been suggested by [95] as an 
effective method of achieving maximum paper recycling. It is our opinion that it could be adopted for all establishments in Nigeria either as a policy statement or a campaign exercise. This would ensure that firms maximize waste paper recovery.

Finance has been identified as another hindrance in this sector [12]. There is a limited existence of short- and mid-term investment funds for industries in Nigeria. The ones available are not easily accessible due to usually attached stringent conditions in the form of unreasonably high interest rates and unfathomable collaterals. Enormous investment opportunities in paper production are either lost or not adequately exploited because of these reasons. The government's support and liberal fiscal instruments by virtue of soft loans, rebates, or grants to encourage small- and middle-scale industries in harnessing more effort in paper production and recycling is also recommended. Nigeria has many private investment promotional laws that are meant to act as incentive for prospective investors. One such law is the 'Nigerian Investment Promotion Commission Act, Cap117, no. 16 of 1995, Laws of Federal Republic of Nigeria' which pronounces 'pioneer status' that confers an up-to five-year tax holiday to new industries or existing ones with plans of expansion. There is also 'Minimum Local Raw Material Utilization Incentive' that grants an up-to 20\% tax credit to companies that source and utilize local raw material for their production. Good enough, paper and pulp industry is listed among the sectors qualified for these incentives. On one part, it is recommended that such laws should be strengthened or revised with increased incentives in order to encourage investments in domestic paper production and recycling. On the other part, the responsible government agencies should create public awareness as many potential investors might not be aware of its existence.

There is equally a great need for institutional efficiency as this portrays the entire imagery strength and character of governance in a country [86]. The existing institutional framework in Nigeria is that the federal ministry of science and technology oversees Raw material Research and Development Council (RMRDC) whose main function is to recommend policies on domestic harnessing of raw material for sustainable industrial development, the Ministry of Environment in charge of Environmental Protection prioritizes high quality environmental performance through their various departments and agencies. For instance, aggressive pursuit of local raw material sources by RMRDC might bring deterrence to forest resources and environmental quality which becomes a problem against the mandate of other agencies. The way forward is that to achieve an optimal result, there is a need to harmonize missions, visions, and objectives of various public institutions and policies playing mutually exclusive roles in the areas of raw material development, natural resource management, and environmental regulations. This becomes necessary as their conflicting and contradicting purposes and intents often leads to poor goal achievement and even losses. Better still, creation of a special task force or committee with delegates drawn from key bodies and interest groups is vital and could yield a kind of synergy necessary for sustainable development [35].

Finally, embarking on a strong campaign to create public awareness on environmental and economic advantages of recycling and also on global incentive of clean technology mechanism (CDM) and carbon markets is an action capable of turning the fortune of paper production in Nigeria. Capacity building has also long been identified as the strategies for addressing the challenge of limited technical abilities [96]. Investing in workshops, seminars, and conferences to train and brainstorm on recycling issues will help in enlarging the population of people with expert knowledge on recycling. Existing environmental legislations should be reviewed to intensify sanctions on burning and outright burying of paper waste.

\section{Conclusions}

Paper is very important commodity and part and parcel of our everyday life. Its production and consumption typically occur with several ecological and economic issues that deserves a careful analysis in order to ensure sustainability. This study explored all the challenges, development and prospects of paper making in Nigeria. The status of domestic paper production in Nigeria as reviewed in this work definitively shows that the local paper industry is currently in a deplorable state. However, 
the status of consumption seems quite opposite when evaluated against the paper products' import trade and the corresponding waste volumes, as it indicates a high demand for these products with a huge prospect of continuous rise. This is suggestive of the opinion that the future of paper making in Nigeria is bright, as long as the hampering issues which center on raw material sources, availability of energy and water supplies, and environmental pollution are adequately tackled. The current study also makes a case for secondary fiber sourcing through recycling as one among several good alternatives for sustainable paper production in Nigeria, with a projection of possible gains from urban solid waste. On this premise, revisiting with the aim of repositioning the current waste management and raw material sourcing policies and practices in the country in order to be in tune with international best practices would be highly instrumental in ensuring optimal availability and utilization of wastepaper in paper production.

Supplementary Materials: The following are available online at http://www.mdpi.com/2079-9276/8/1/53/s1.

Author Contributions: O.B.E.; conceptualized, investigated and wrote the original manuscript. O.B.E.; curated and formally analyzed the research data. O.B.E. and I.C.E.; edited and revised the manuscript. J.C.A.; supervised the project. J.C.A. and C.N.M.; project administration.

Funding: This research received no external funding.

Acknowledgments: We thank the anonymous reviewers and the academic editor for their constructive criticism towards improving the quality of the manuscript. Obiora B. Ezeudu is grateful for the support received from his brother, Martin-Joe Ezeudu.

Conflicts of Interest: The authors declare no conflict of interest.

\section{References}

1. Environmental Paper Network (EPN): The State of the Global Paper Industry 2018. Available online: http:/ / environmentalpaper.org/tools-and-resources/reports/ (accessed on 4 December 2018).

2. Suhr, M.; Klein, G.; Kourti, I.; Gonzalo, M.R.; Santoja, G.G.; Roudier, S.; Sancho, L.D. Best Available Techniques (BAT) Reference Document for the Production of Pulp, Paper and Board (Industrial Emissions Directive 2010/75/EU; Publications Office of the European Union: Luxembourg, Luxembourg, 2015; p. 906.

3. Berg, P.; Lingqvist, O. Pulp, Paper and Packaging in the NEXT decade: Transformational Change. McKinsey \& Company, 2017. Available online: https:/ /www.mckinsey.com/industries/paper-and-forestproducts/our-insights/pulp-paper-and-packaging-in-the-next-decade-transformational-change (accessed on 12 November 2018).

4. FAO. Trends and Current Status of the Contribution of the Forestry Sector to National Economies. 2004. Available online: http://www.fao.org/docrep/007/ad493e/ad493e00.htm\#TopOfPage (accessed on 12 November 2018).

5. Smith, R. The Environmental Sustainability of Paper. Grad. Stud. J. Organ. Dyn. 2011, 1, 1-12.

6. Xiong, B.; Zhang, X.; Li, F.; Hu, H.; Liu, C. Recycling of Aluminum A380 Machining Chips. Light Metals 2015: Cast Shop for Aluminum Productio. In Proceedings of the TMS 2015 144th Annual meeting and Exhibition, Orlando, FL, USA, 15-19 March 2015; pp. 1011-1015.

7. Thomas, M.P.; Wirtz, A.H. The ecological demand and practice for recycling of aluminum. Resour. Conserv. Recycl. 1994, 10, 193-204. [CrossRef]

8. Egbewole, Z.T.; Rotowa, O.J. Effects of Declining paper industry in Nigeria economy and the way forward. Am. J. Agric. For. 2017, 5, 181-187.

9. Ogunwusi, A.A.; Ibrahim, H.D. Advances in Paper and pulp Technology and the Implication for the Paper industry in Nigeria. Ind. Eng. Lett. 2014, 4, 3-11.

10. Aruofor, R. Forestry Outlook Studies in Africa: A Brief on the Forestry Outlook Study. 2011. Available online: http:/ / www.fao.org/forestry/FON/FONs/outlook/Africa/AFRhom-e-stm (accessed on 12 October 2018).

11. Adegbohin, J.O.; Omijeh, J.E. Raw Material for the Pulp and paper industry in Nigeria. Commonww. For. Rev. $1989,68,10$.

12. Ogunwusi, A.A.; Onwualu, A.P. Impact of Privatization of Primary Pulp and Paper Mills on Performance of the Pulp and paper Sector in Nigeria. Dev. Country Stud. 2013, 3, 109-119. 
13. Azeez, M.A.; Andrew, J.E.; Sithole, B.B. A preliminary investigation of Nigerian Gmelina arborea and Bambusa vulgaris for pulp and paper production. Maderas Ciencia Y Tecnología 2016, 18, 65-78.

14. Udohitinah, J.S.; Oluwadare, A.O. Pulping properties of Kraft Pulp of Nigerian- Grown Kenaf (Hibiscus Cannabinus L.). Bioresources 2011, 6, 751-761.

15. Chokor, B.A. Government Policy and Environmental Protection in Developing World. The Example of Nigeria. Environ. Manag. 1993, 17, 15-30. [CrossRef]

16. Johnson, A. Environmental Systems Analysis Tools as Decision-Support in Municipal Solid Waste Management-LCA in Sweden, Estonia and Lithuania; Uppsala University: Uppsala, Sweden, 2013; p. 40. Available online: http: / / www.diva-portal.org/smash/get/diva2:646898/fulltext01.pdf (accessed on 7 March 2019).

17. Ecology Global Network. Available online: http://www.ecology.com/2011/09/10/paper-chase/ (accessed on 18 October 2018).

18. Environmental Defense Fund. Paper Task Force Recommendations for Purchasing and Using Environmentally Preferable Paper; Environmental Defense Fund: New York, NY, USA, 1995; p. 249.

19. Hughes, S.B.; Willis, D.M. How quality control Concepts can reduce environmental expenditure. J. Cost Manag. 1995, 9, 15-19.

20. FAO. The State of the World's Forest. 2018: Forest Pathway to Sustainable Development. Available online: http:/ / www.fao.org/3/I9535EN/i9535en.pdf (accessed on 1 December 2018).

21. Schumacher, K.; Sathaye, J. India's Paper Industry: Productivity and Efficiency; A Report of the Earnest Orland Lawrence Bakery; National Laboratory: Bakery, CA, USA, 1999; p. 37. Available online: https: / / pdfs.semanticscholar.org/6156/77e9dd5b6277936947ffb1209cb3be42d625.pdf (accessed on 7 March 2019).

22. Fracaro, G.; Vakkilainen, E.; Hamaguchi, M.; Melegari de Souza, S.N. Energy Efficiency in the Brazilian Pulp and Paper Industry. Energy 2012, 5, 3550-3572. [CrossRef]

23. Paper Manufacturers Association of South Africa. 2018. Available online: http://www.engineeringnews. co.za/article/paper-manufacturers-association-of-south-africa-2018-03-30/rep_id:4136 (accessed on 1 December 2018).

24. American Forest \& Paper Association. 2010. AF\&PA Sustainability Report. Available online: http://www. afandpa.org/WorkArea/linkit.aspx?LinkIdentifier=id\&itemID=1402 (accessed on 12 November 2018).

25. World Economic Forum: Global Agenda Council on the Future of Oil and Gas. Geneva, Switzerland, 2016. Available online: https:/ / www.weforum.org/whitepapers/future-of-oil-gas (accessed on 12 November 2018).

26. IEA, Energy Efficiency Market Report. 2016. Available online: https://www.ies.org/eemr16 (accessed on 21 November 2018).

27. International Energy Agency (IEA). World Energy Outlook 2017: Global Shift in the Energy. Available online: https:/ / www.iea.org/weo2017/ (accessed on 12 December 2018).

28. Ozoegwu, C.G.; Mgbemene, C.A.; Ozor, P.A. The Status of Solar energy Integration and Policy in Nigeria. Renew. Sustain. Energy Rev. 2017, 70, 457-471. [CrossRef]

29. Chea, A.F. Causes and Sources of Waste in the Printing Industry. Int. Bus. Res. 2008, 1, $22-31$.

30. Carver, J.; Guidry, N. Rethinking Paper and Ink: The Sustainability Publishing Revolution; Ooligan Press: Portland, OR, USA, 2011.

31. Ivana, B.M.; Igor, M.; Bolanca, Z. Ecological Sustainability and waste Paper Recycling. Proceedia Eng. 2015, 100, 177-186.

32. Pivnenko, K.; Olsson, M.E.; Gotze, R.; Eriksson, E.; Astrup, T.F. Quantification of chemical contaminants in the paper and board fractions of municipal solid waste. Waste Manag. 2016, 51, 43-54. [CrossRef]

33. Ramazani, O.; Kermanian, H.; Raempour, Z.; Rahmaninia, M. Water Consumption Reduction Strategies in Recycled Paper Production Companies in Iran. In Proceedings of the International Conference on Information and Communications Technology for Sustainable Agric-Production and Environment, Skiathos, Greece, 8-11 September 2011; pp. 8-11. Available online: http:/ / ceur-ws.org/Vol-1152/paper77.pdf (accessed on 7 March 2019).

34. Environmental Paper Network: The State of the Global Paper Industry. 2018. Available online: http:/ / environmentalpaper.org/wpcontent/uploads/2018/04/StateOfTheGlobalPaperIndustry2018_ FullReport-Final-1.pdf (accessed on 8 January 2019).

35. FAO. Yearbook 2015. Forest Products. Available online: http://www.fao.org/3/a-i6669e.pdf (accessed on 12 November 2018). 
36. UNESCO. Global Educational Monitoring Reports: Education for People and Planet, Creating Sustainable Future for all. 2016. Available online: http://unesdoc.unesco.org/images/0024/002457/245752e.pdf (accessed on 19 November 2018).

37. Population Reference Bureau. 2017. Available online: http://www.worldpopdata.org/ (accessed on 10 October 2018).

38. Ezeudu, O.B.; Ozoegwu, C.G.; Madu, C.N. A Statistical Regression Method for Characterization of Household Solid Waste: A Case Study of Awka Municipality in Nigeria. Recycling 2019, 4, 1. [CrossRef]

39. RMRDC. National Strategy for Competitiveness in Raw Material and Product Development in Nigeria; RMRDC: Abuja, Nigeria, 2016; p. 266.

40. The Nigerian Voice. N400BN Loss to Paper Import. 2010. Available online: https:/ /www.thenigerianvoice. com/news/30327/n400bn-loss-to-paper-imports.html (accessed on 12 November 2018).

41. Trade Economics: Nigeria Import from India. Available online: https://tradingeconomics.com/nigeria/ imports/india (accessed on 25 January 2019).

42. Oyedepo, S.O. On energy for Sustainable development in Nigeria. Renew. Sustain. Energy Rev. 2012, 16, 2583-2598. [CrossRef]

43. World Bank. Water Supply and Sanitation in Nigeria. 2000. Available online: http:/ / siteresources.worldbank. org/NIGERIAEXTN/Resources/wss_1100.pdf (accessed on 8 December 2018).

44. Emenike, C.P.; Tenebe, I.T.; Omole, D.O.; Ngene, B.U.; Oniemayin, B.I.; Maxwell, O.; Onoka, B.I. Accessing Safe drinking water in sub-Sahara Africa: Issues and Challenges in South-West Nigeria. Sustain. Cities Soc. 2017, 30, 263-272. [CrossRef]

45. Ojo, E. Manufacturer's Need 2000MW of Electricity to Stay Afloat; MAN, Lagos. Business Day Nigeria; MAN: Lagos, Nigeria, 2009.

46. Scarlet, N.; Motola, V.; Dallemand, J.F.; Monforti-Ferrari, F.; Mofor, L. Evaluation of Energy Potential of Municipal Solid Waste from African Urban Areas. Renew. Sustain. Energy Rev. 2015, 50, 1269-1286. [CrossRef]

47. Population Reference Bureau. 2018 World Population Data Sheet with Focus on Changing Age Structure. Available online: https:/ / www.prb.org/2018-world-population-data-sheet-with-focus-on-changing-agestructures/ (accessed on 11 November 2018).

48. The Statista Portal. Available online: https://www.statista.com/statistics/546572/pulp-and-paperproduction-market-share-in-africa-by-country/ (accessed on 28 January 2019).

49. Nairametrics. Nigeria loses N180 Billion Due to Collapse of 3 Paper Mills. Available online: https:// nairametrics.com/2015/09/21/nigeria-loses-n180bn-due-to-the-collapse-of-3-paper-mills / (accessed on 16 June 2017).

50. Ibrahim, H.D.; Hammanga, S.I.; Wali, S.L.; Aniebue, E.N. Policy Brief on the Production of Toilet Paper in Nigeria; RMRDC: Abuja, Nigeria, 2015; 52p.

51. The Brookings Institute. Africa in Focus, Youth Unemployment in Nigeria. A situation Analysis. Available online: https: / / www.brookings.edu/blog/africa-in-focus/2014/09/23/youth-unemployment-in-Nigeria (accessed on 24 January 2017).

52. National Population Commission (NPC) [Nigeria] and ICF International. Nigeria Demographic and Health Survey 2013. Abuja, Nigeria, and Rockville, Maryland, USA: NPC and ICF International. 2014. Available online: https: / / dhsprogram.com/pubs/pdf/fr293/fr293.pdf (accessed on 1 September 2018).

53. RMRDC. National Strategy for Competitiveness in Raw Material and Products Development in Nigeria: Implementation Plan; RMRDC: Abuja, Nigeria, 2017; p. 154.

54. Premium Times. How We Made It in Africa. Published 27 September 2018. Available online: https:/ /opinion.premiumtimesng.com/2018/09/29/manufacturing-in-nigeria-status-challengesand-opportunities-by-rafiq-raji/ (accessed on 12 December 2018).

55. Asthana, D.K. Text Book of Environmental Studies; S. Chand \& Company Ltd.: New Delhi, India, $2006 ;$ p. 397.

56. Suberu, M.K.; Mokhtar, A.S.; Bashir, N. Renewable Power Generation Opportunity from Municipal Solid Waste: A Case Study of Lagos Metropolis (Nigeria). J. Energy Technol. Policy 2012, 2, 1-12.

57. The World Bank. What A Waste: A Global Review of Solid Waste Management. The Urban Development Series Knowledge Papers; The World Bank: Washington, DC, USA, 2012.

58. Allesch, A.; Brunner, P.H. Assessment methods for solid waste management: A Literature Review. Waste Manag. Res. 2014, 32, 461-473. [CrossRef] 
59. Vidovic, M.; Ratkovic, B.; Bjelic, N.; Popovic, D. Optimization of Recyclables collection Processes. Oper. Supply Chain Manag. 2011, 4, 90-98. [CrossRef]

60. American Forest and Paper Association. 2018. Available online: https://www.afandpa.org/media/news/ 2018/07/24/u.s.-paper-and-wood-products-manufacturers-report-sustainability-progress (accessed on 12 December 2018).

61. Charles, P.; Godin, J. Development of CDM Methodology for Recycling Activities. World Bank, 2009. Available online: http:/ / siteresources.worldbank.org/INTCARBONFINANCE/Resources/P.MSW.ISWAWorldCongress. RecyclingMeth.pdf (accessed on 12 November 2018).

62. Agunwamba, J.C. Solid Waste Management in Nigeria, Problems and Issues. Environ. Manag. 1998, 22, 849-856. [CrossRef]

63. Ogwueleka, T.C. Analysis of Urban solid waste in Nsukka: Nigeria. J. Solid Waste Technol. Manag. 2003, 4, 239-246.

64. Ajaero, C.K.; Nzeadigo, T.C. Informal waste recycling and urban governance in Nigeria; Some experience and Policy Implications. In Handbook of Environmental Policy; Nova Science Publishers: Hauppauge, NY, USA, 2010.

65. Agunwamba, J.C. Analysis of scavengers' activities and recycling in some cities of Nigeria. Environ. Manag. 2003, 32, 116-127. [CrossRef]

66. Nzeadigo, T.C.; Iwuoha, H.C. Informal waste Recycling in Lagos, Nigeria. Commun. Waste Resour. Manag. 2008, 9, 24-30.

67. Sridhar, M.K.; Hammed, T.B. Turning waste to wealth in Nigeria: An Overview. J. Hum Ecol. 2014, 46, 195-205. [CrossRef]

68. Oladepo, O.W.; Ilori, M.A.; Taiwo, K.A. Assessment of waste generation and management practices in Nigerian food industry: Towards a policy for sustainable approaches. Am. J. Sci. Ind. Res. 2014, 6, $12-22$.

69. Nnaji, C.C. Status of Municipal Solid Waste generation and disposal in Nigeria. Manag. Environ. Qual. Int. J. 2015, 26, 53-71. [CrossRef]

70. Sha'Ato, R.; Aboho, S.Y.; Oketunde, F.O.; Eneji, I.S.; Unazi, G.; Agwa, S. Survey of solid waste generation and composition in a rapidly growing urban area in Central Nigeria. Waste Manag. 2007, 27, 352-358. [CrossRef]

71. Ogwueleka, T.C. Survey of household waste composition and quantities in Abuja, Nigeria. Resour. Conserv. Recycl. 2013, 77, 52-60. [CrossRef]

72. Imam, A.; Mohammed, B.; Wilson, D.C.; Cheeseman, C.R. Solid Waste management in Abuja, Nigeria. Waste Manag. 2008, 28, 468-472. [CrossRef]

73. Cointreau, S.J. Environmental Management of Urban Solid Waste in Developing Countries: A Project Guide; Urban Development Technical Paper No 5; World Bank: Washington, DC, USA, 1982.

74. Ogwueleka, T.C. Municipal Solid Waste Characteristics and management in Nigeria. Iran J. Environ Health Sci Eng. 2009, 6, 173-180.

75. Afon, A. An analysis of urban solid waste generation in a traditional African city: The example of Ogbomosho, Nigeria. Env. Urban. 2007, 19, 525-537.

76. Trading Economics: Nigeria-Urban Population(\% of total). Available online: https://tradingeconomics. com/nigeria/urban-population-percent-of-total-wb-data.html (accessed on 7 March 2019).

77. Olukanni, D.O.; Aipo, A.O.; Kalabo, I.H. Recycling and Reuse Technology: Waste to Wealth Initiative in a private Tertiary institution, Nigeria. Recycling 2018, 3, 44. [CrossRef]

78. Dangi, M.B.; Urynowicz, M.A.; Belbase, S. Characterization, generation, and management of household solid waste in Tulsipur, Nepal. Habitat Int. 2013, 40, 65-72. [CrossRef]

79. UN-HABITAT. Collection of Municipal Solid Waste in Developing Countries; United Nations Human Settlement Programme: Nairobi, Kenya, 2010.

80. Egunjobi, L. Our Gasping Cities; An Inaugural Lecture; University of Ibadan: Ibadan, Nigeria, 1999.

81. United Nations, Department of Economic and Social Affairs, Population Division. World Urbanization Prospects. The 2018 Revision Online Edition. Available online: https:/ / population.un.org/wup/Download/ (accessed on 1 December 2018).

82. Aliyu, A.A.; Amadu, L. Urbanization, Cities and Health: The challenge of Nigeria-A review. Ann. Afr. Med. 2018, 16, 149-158. [CrossRef]

83. RMRDC. Raw Material Sourcing for Manufacturing in Nigeria, 4th ed.; Raw Material Research and Development Council: Abuja, Nigeria, 2009. 
84. Federal Ministry of Environment. Policy Guideline on Solid Waste Management. 2005. Available online: http: / / tsaftamuhalli.blogspot.com (accessed on 25 November 2018).

85. UN-Habitat. Solid Waste Management in the World's Cities: Water and Sanitation in the World's Cities; Earthscan: London, UK, 2010.

86. Wingqvist, G.O.; Drakenberg, O.; Slunge, D.; Sjostedt, M.; Ekbom, D. The Role of Governance for Improved Environmental Outcomes: Perspectives for Developing Countries and Countries in Transition; Swedish Environmental Protection Agency: Stockholm, Sweden, 2012; p. 59.

87. Medina, M. The World's Scavengers: Salvaging for Sustainable Production and Consumption (Globalization and the Environment); AltraMira Press: Plymouth, UK, 2007; p. 320.

88. Scheinberg, A.; Anschutz, J.; Van de Klundert, A. Waste Pickers: Poor victims or waste management profesionals? In Solid Waste, Health and the Millennium Development Goals; CWG-WASH Workshop; CWH-WASH: Kolkata, India, 2006.

89. Wilson, D.C.; Velis, C.; Cheeseman, C. Role of Informal Sector Recycling in waste management in developing countries. Habitat Int. 2006, 30, 797-808. [CrossRef]

90. Birkbeek, C. Garbage Industry and the "vulture" of Cali, Columbia. In Casual Work and Poverty in Third World Cities; Bromley, R., Gerry, C.C., Eds.; Wiley: New York, NY, USA, 1979; pp. 161-183.

91. Ukpong, E.C.; Udo, E.A.; Umoh, I.C. Characterization of materials from ABA waste dumpsites. Int. J. Eng. Appl. Sci. 2015, 6, 1-10.

92. The Eagle. Available online: https://theeagleonline.com.ng/towards-better-waste-management-regime-inlagos-by-adebayo-samuel/ (accessed on 14 November 2018).

93. Usman, S. Environmental Impact Assessment and FCT Responsibility. Published on Daily Trust, 17 August 2015. Available online: https:/ / www.dailytrust.com.ng/environmental-impact-assessment-and-fctresponsibility.html (accessed on 11 December 2018).

94. Muzenda, E. Recycling situation in South Africa: A discussion. Int. J. Biol. Ecol. Environ. Sci. 2013, 2, 2277-4394.

95. Pati, R.K.; Vrat, P.; Kumar, P. A goal programming model for paper recycling system. Omega 2008, 36, 405-417. [CrossRef]

96. Saidi, T.A. Environmental Impact Assessment as a Policy Tool for Integrating Environmental Concerns in Development; AISA Policy Brief; AISA: Pretoria, South Africa, 2010; Available online: http: / / www.ai.org.za/wp-content/uploads/downloads/2011/11/No-19.-Environmental-Impact-Assessmentas-a-Policy-Tool-for-Integrating-Environmental-Concerns-in-development.pdf. (accessed on 7 March 2019). 